\title{
Neurodevelopmental outcome following therapeutic hypothermia for perinatal asphyxia
}

\author{
Smail Zubčević, Suada Heljić, Raho Spahović, Ismeta Kalkan, Sabina Terzić, Mirna Sadiković*
}

Studies are supporting neuroprotective benefit of therapeutic hypothermia in term newborns with hypoxic-ischemic encephalopathy. We assessed survival and neurodevelopmental outcome of neonates subjected to the procedure and factors that may have influenced it. Newborns with gestational age of more than 36 weeks and less than 6 hours of age with moderate to severe asphyxial encephalopathy underwent cooling protocol at a temperature of $33.5^{\circ} \mathrm{C}$ for 72 hours and rewarming period of 6 hours. The outcome measures assessed were death and neurodevelopmental characteristics. Twenty-five children were assessed during the period from October 2010 to October 2013. Median gestational age was 40 weeks, birth weight $3470 \mathrm{~g}$, Apgar score 2/4 and pH on admission to the hospital 7.02. Four (16\%) children died and two were lost for follow up. At the age of final assessment, developmental categories of communication were normal in $68.4 \%$, problem solving in $73.7 \%$, personal-social in $68.4 \%$, gross motor in $57.9 \%$, and fine motor in $36.8 \%$ but with a high need of retesting in this area. Seven of 19 patients (36.8\%) had completely normal results for all five categories, while three (15.8\%) had abnormal results for all categories. None of the 18 parameters that were correlated with neurodevelopmental outcome showed statistical significance. Amplitude integrated electroencephalography was done in ten patients and the most prominent finding was discontinuous activity in eight patients. In conclusion, a relatively small number of patients and limitations of this study design precluded any far-reaching conclusions, but we think that this method can provide better survival and less neurologic sequels in hypoxic-ischemic encephalopathy patients.

Keywords: asphyxia neonatorum; hypothermia; infant, newborn

\section{INTRODUCTION}

Hypoxic-ischemic encephalopathy (HIE) is a major cause of morbidity and mortality in neonates despite important progress in obstetric and neonatal care during the last decades. According to Lawn et al. (1), it is the fifth most common cause of death in children under 5 years. Perinatal asphyxia affects 3-5 newborns per 1000 live births with subsequent moderate or severe hypoxic ischemic encephalopathy in 0.5 to 1 per 1000 live births in developed countries (2). These numbers are twice or more in developing countries (3). Studies show that 10\% to $60 \%$ of affected infants die, and at least $25 \%$ of survivors have long-term neurodevelopmental sequels (4).

Therapeutic approach for treating neonatal encephalopathy has to be based on the understanding of the mecha- nisms of neuronal damage following hypoxic-ischemic brain injury. That pathway is probably our clue for finding the best possibilities for preventing brain injury in asphyxiated neonates. Animal models show that many factors play a role, e.g., etiology, extent of hypoxia or ischemia, maturation stage of the brain, regional cerebral blood flow, and general health prior to the injury can all impact the pattern and extent of brain injury as well as outcome following the injury (5). Results of previous studies on this subject indicate

\footnotetext{
* Pediatric Hospital, University Clinical Center, Sarajevo, Bosnia and Herzegovina
}

\section{Correspondence to:}

Assist. Prof. Smail Zubčević, MD, PhD, Pediatric Hospital, University Clinical Center, Sarajevo, Patriotske lige 81, 71000 Sarajevo,

Bosnia and Herzegovina; e-mail: smail.zubcevic@gmail.com

Primljeno/Received: 3. 2. 2014., Prihvaćeno/Accepted: 19. 3. 2014. 
that some other factors can play additional role, especially in developing countries, such as maternal nutrition, infections, late admission to hospital, lengthy decision making for cesarean section, etc. Today, general understanding of the pathophysiological processes in HIE is that the initial hypoxic-ischemic insult brings immediate cell loss of varying degrees, but delayed impairment in energy metabolism leads to more significant cell loss by apoptotic cell death.

One of the ideas to try ameliorating this secondary brain injury is by putting neonates at risk of developing moderate to severe HIE on therapeutic hypothermia. A review of animal studies showed that brain cooling to $32{ }^{\circ} \mathrm{C}$ to $34^{\circ} \mathrm{C}$, beginning before 5.5 hours following hypoxic-ischemic injury and continued for 12-72 hours, reduced secondary energy failure and cell death and was associated with neuropathological and functional improvements (6). Several human trials in which cooling was initiated as early as feasible after brain injury (but before 6 hours) and in which neonates rectal/esophageal temperature was reduced to 32 ${ }^{\circ} \mathrm{C}$ to $34{ }^{\circ} \mathrm{C}$ showed promising results. The potential mechanisms of neuroprotection with hypothermia include inhibition of glutamate release, reduction of cerebral metabolism, which in turn preserves high energy phosphates, decrease in intracellular acidosis and lactic acid accumulation, preservation of endogenous antioxidants, reduction of nitric oxide production, prevention of protein kinase inhibition, improvement of protein synthesis, reduction of leukotriene production, prevention of blood-brain barrier disruption and brain edema, and inhibition of apoptosis $(7,8)$. Randomized controlled trials such as the CoolCap study (9), National Institute for Child Health and Human Development (NICHD) Neonatal Research Network (10), TOBY Trial (11) and ICE Trial (12) have led to a growing number of centers around the world deciding to make this procedure part of their routine work. Two major different methods are present today: whole-body cooling (nowadays prevailing) and selective head cooling (less used). There is no mutual consensus if one of these is superior, and debate is still going on (13).

In this study, we tried to assess the outcome of children treated with therapeutic hypothermia for moderate and severe perinatal asphyxia, as well as the influence of several factors presented at admission to the hospital and discharge from the hospital on neurodevelopmental outcome.

\section{PATIENTS AND METHODS}

We assessed neurodevelopmental outcome of 25 children at different age, which were after birth treated with therapeutic hypothermia. Infants were eligible for consideration of such a treatment if they were born at or after 36 completed weeks of gestation.
Protocols for selecting patients for therapeutic hypothermia treatment were revised from TOBY study and so called Bristol Cooling Protocol (14-16). Revisions were made in a way that criteria for inclusion in hypothermia treatment by performing amplitude-integrated electroencephalography (aEEG) read by trained personnel were not obligatory if other criteria were met, and aEEG was done only in several patients.

This meant that infants with more than 36 weeks of gestation, and with at least one of the following: Apgar score $\leq 5$ at ten minutes after birth, continued need for resuscitation, including endotracheal or mask ventilation at 10 minutes after birth, acidosis defined as either umbilical cord $\mathrm{pH}$ or any arterial, venous or capillary pH within 60 min of birth less than 7.00, or base deficit greater than or equal to 16 $\mathrm{mmol} / \mathrm{L}$ in umbilical cord blood sample or any blood sample within 60 minutes of birth (arterial or venous blood), were eligible for further evaluation for cooling. Next criteria were moderate to severe encephalopathy, consisting of altered state of consciousness (lethargy, stupor or coma), and at least one or more of the following: persistent hypotonia after successful resuscitation, abnormal reflexes including oculomotor or pupillary abnormalities, absent or weak suck, and clinical seizures as recorded by trained personnel. Children who meet these criteria largely correspond to stage ॥ and III of Sarnat grading scale of HIE.

Only three infants in this group were studied by aEEG prior to cooling process, for at least 30 minutes duration, and another seven were monitored during cooling process. aEEG was assessed as: with continuous, normal background voltage without electrical seizure activity, moderately abnormal voltage (upper margin of trace $>10 \mu \mathrm{V}$ and lower margin of trace $\langle 5 \mu \mathrm{V}$ ), discontinuous, suppressed activity (upper margin of trace $<10 \mu \mathrm{V}$ and lower margin of trace $<5 \mu \mathrm{V}$, and for seizure activity. aEEG was done with Nicolet ICU Monitor (CareFusion Corporation, San Diego, California, USA); four electrodes were placed in the P3-P4 and C3-C4 areas, fifth electrode (neutral electrode) was placed to the front of the midline as a ground for noise immunity placement of electrodes.

Cooling duration was 72 hours, with at least 6 hours of rewarming. Rectal temperatures were set to $33.5^{\circ} \mathrm{C}$. Cooling was performed by the Arctic Sun Temperature Management System (Medivance, Louisville, Colorado, USA) as a thermoregulatory device that monitors and controls patient temperature within a range of $32^{\circ} \mathrm{C}$ to $38.5^{\circ} \mathrm{C}$. The system consists of the Model 2000 and disposable Arctic Gel hydrogel coated pads. Cooling and rewarming was done in a preprogrammed way.

Mortality was ascertained up to the latest follow up. Children were followed-up for their neurodevelopment through 
regular visits at child neurology outpatient clinic, through a structured examination by one trained assessor. At the moment of finishing study, cross-sectional evaluation of their development was done by the parent and assistant, completing questionnaires based on the Ages \& Stages Questionnaires (ASQ-3), adopted in a way described by Kapci et al. (17), and use it as part of the project of introducing early intervention programs in Bosnia and Herzegovina. We decided to base our neurodevelopmental assessment on this parent-completed developmental and social-emotional screener questionnaire because of its highly valid, reliable and accurate results that span across the spectrum of ages, since we did not have enough patients in the age group above 18 or 24 months. ASQ shows sensitivity of $92 \%$, 95\% specificity, 92\% positive predictive value and 95\% negative predictive value when used to detect severe developmental delay; and 67\% sensitivity, 93\% specificity, 92\% positive predictive value and $68 \%$ negative predictive value when used to detect both severe and mild developmental delay in children with neonatal HIE (18). It has very good correlation with more sophisticated, time consuming tests, like Bayley scale, which require investigators' thorough education (19). Parents were instructed to fill in the questionnaire during follow up visit. In the period of assessment, children were aged 4-36 months.

The IBM SPSS 20 software package was used for statistical analyses; descriptive statistics was used for description of the variables, means, medians, ranges and distribution of data. Mann-Whitney U Test was used to show significance of independent variables in relation to dependent (neurodevelopmental outcome). Linear regression was tested.

\section{RESULTS}

The study was conducted from October 2010 to October 2013 at Pediatric Hospital, Sarajevo University Clinical Center, Sarajevo, Bosnia and Herzegovina. Children were recruited for the study from two maternity hospitals in Sarajevo and 9 other different maternity hospitals in Bosnia and Herzegovina.

Compliance with the protocol was not complete in two patients, where cooling started after the age of 6 hours, due to decision of doctors on ward at that time. Baseline characteristics of the infants are shown in Table 1.

Patient outcome, survival and age at testing according to categories of communication, gross motor, fine motor, problem solving, and personal-social skills for each of our patients treated with therapeutic hypothermia for perinatal asphyxia are shown in Table 2. Four (16\%) patients died and two (8\%) were lost during follow up, but with no indication that they died.
TABLE 1. Baseline characteristics of infants treated with therapeutic hypothermia for perinatal asphyxia

\begin{tabular}{ll}
\hline Male/Female & $13 / 12$ \\
Gestational age (wks, range) & $37-42$ \\
Gestational age (wks, median) & 40 \\
Birth weight (g, range) & $2220-4950$ \\
Birth weight (g, median) & 3470 \\
Head circumference (cm, range) & $33-37$ \\
Head circumference (cm, median) & 35 \\
Apgar score at 1/5 minutes (range) & $0 / 5-1 / 6$ \\
Apgar score at 1/5 minutes (median) & $2 / 4$ \\
Age at starting cooling (hours, range) & $2-8$ \\
Age at starting cooling (hours, median) & 4 \\
pH at admission to hospital (range) & $6.49-7.25$ \\
pH at admission to hospital (median) & 7.02 \\
Resuscitation required at 10 min of age, n (\%) \\
Clinical seizures prior to cooling, n (\%)
\end{tabular}

We were able to get ASQ-3 questionnaires for 19 of our patients at the time of finishing our follow up and their neurodevelopmental outcome according to the results from ASQ-3 questionnaires is presented in Table 3.

It is worth noting that seven of 19 patients (36.8\%) had completely normal results for all five categories, while three (15.8\%) had abnormal results for all categories. We tried to assess whether some of the parameters that were recorded at birth as well as during the recruiting process for therapeutic hypothermia and during hospital stay had any correlation with neurodevelopmental outcome. There was no statistically significant correlation between these parameters and neurodevelopmental outcome. Results are shown in Table 4.

We also tried to see if some features from neurological examination of the child on discharge from the hospital after therapeutic hypothermia for perinatal asphyxia could be correlated with outcome, and whether scoring these examinations (0 point - Abnormal, 1 point - Normal) could be helpful in predicting neurodevelopmental outcome. We did not find any statistically significant correlation. Results are shown in Table 5.

Ten children in our group were monitored by aEEG, three prior and during, and seven only during therapeutic hypothermia. A prominent finding in eight of these patients was discontinuous background activity as described before, and two had a burst suppression pattern during recording.

\section{DISCUSSION}

The lack of specific interventions to improve frequently poor prognosis of neonates with moderate to severe peri- 
TABLE 2. Outcome of patients treated with therapeutic hypothermia for perinatal asphyxia

\begin{tabular}{|c|c|c|c|c|c|c|}
\hline No. & $\begin{array}{l}\text { Age at testing } \\
\text { (months) }\end{array}$ & Communication & Gross Motor & Fine Motor & Problem Solving & Personal-Social \\
\hline 1 & 20 & Normal & Normal & Normal & Normal & Normal \\
\hline 3 & 12 & Normal & Normal & Normal & Normal & Normal \\
\hline 4 & Died & & & & & \\
\hline 6 & 4 & Normal & Normal & Normal & Normal & Normal \\
\hline 7 & $\mathrm{n} / \mathrm{a}$ & $n / a$ & $\mathrm{n} / \mathrm{a}$ & $\mathrm{n} / \mathrm{a}$ & $\mathrm{n} / \mathrm{a}$ & $\mathrm{n} / \mathrm{a}$ \\
\hline 8 & 8 & Normal & Normal & Normal & Normal & Normal \\
\hline 9 & 27 & Normal & Normal & Normal & Normal & Normal \\
\hline 10 & 4 & Normal & Normal & Retesting & Retesting & Abnormal \\
\hline 12 & 22 & Abnormal & Abnormal & Abnormal & Abnormal & Abnormal \\
\hline 13 & 12 & Normal & Hemiparesis & Retesting & Normal & Normal \\
\hline 14 & 22 & Abnormal & Normal & Abnormal & Normal & Retesting \\
\hline 15 & Died & & & & & \\
\hline 16 & 4 & Abnormal & Normal & Abnormal & Abnormal & Abnormal \\
\hline 17 & 36 & Normal & Normal & Retesting & Normal & Normal \\
\hline 18 & Died & & & & & \\
\hline 19 & Died & & & & & \\
\hline 20 & 24 & Normal & Normal & Normal & Normal & Normal \\
\hline 21 & 4 & Normal & Retesting & Retesting & Normal & Normal \\
\hline 24 & 27 & Retesting & Retesting & Retesting & Normal & Normal \\
\hline 25 & 16 & Abnormal & Abnormal & Abnormal & Abnormal & Abnormal \\
\hline
\end{tabular}

natal asphyxia had made neonatologists eager to try novel treatments. Hypoxic-ischemic encephalopathy presents a huge problem for later health care of those patients, carrying significant morbidity and mortality rates and leading to a significant burden on society. In the last decade, one of the most promising new treatments has been therapeutic hypothermia for perinatal asphyxia.

Since this method is in widespread use in the world for less than 5 years, randomized trials are still scarce, and data from them are sometimes contradictory. A recent meta-analysis (18), however, states that it strongly supports the use of therapeutic hypothermia in newborns with HIE to reduce the risk of death and neurologic impairment at 18 months. But some other studies still show that a lot of things regarding therapeutic hypothermia have to be answered, and possibly, adjusting of therapy should be done in the coming years (19).

Nowadays, many medical centers are starting 'cooling programs', not only in highly developed countries, but also in developing countries. Results from less developed countries do not always correlate with those in highly developed countries, due to several reasons, and for this problem we have to put accent on factors such as maternal nutrition, scope of prenatal and perinatal infections, less developed medical transport services, lack of adequate hospital facilities, late admission to hospital and lengthy decision making for cesarean section, etc. That is why we tried to compare the results from Bosnia and Herzegovina with the results from other highly developed countries.

Our sample for the past three years was quite small and neurodevelopmental follow up frequently not long enough to make far-reaching conclusions. Our mortality rate for the followed period, four out of 25 patients (16\%), was comparable or lower than in most other studies (9-12). From the available data, it is hard to comment on this, since there was no major difference in asphyxia severity, and our percentage can be part of a small number of patients we had in our group. 
TABLE 3. Neurodevelopmental outcome according to results of the Ages \& Stages Questionnaires (ASQ-3)

\begin{tabular}{llllll}
\hline & Communication & Gross Motor & Fine Motor & Problem Solving & Personal - Social \\
Normal & $13(68,42 \%)$ & $11(57,89 \%)$ & $7(36,84 \%)$ & $14(73,68 \%)$ & $13(68,42 \%)$ \\
Abnormal & $5(26,31 \%)$ & $\begin{array}{l}6(31,58 \%) \\
(3 \text { Hemiparesis) }\end{array}$ & $5(26,31 \%)$ & $4(21,05 \%)$ & $5(26,31 \%)$ \\
Retesting zone & $1(5,26 \%)$ & $2(10,53 \%)$ & $7(36,84 \%)$ & $1(5,26 \%)$ & $1(5,26 \%)$ \\
Total & 19 & 19 & 19 & 19 & 19
\end{tabular}

TABLE 4. Correlation of different parameters with neurodevelopmental outcome (level of statistical significance)

\begin{tabular}{|c|c|c|}
\hline & $\begin{array}{l}\text { Asymp. Sig. } \\
\text { (2-tailed) }\end{array}$ & $\begin{array}{l}\text { Exact Sig. (1-tailed Sig.) } \\
\text { (Not corrected for ties) }\end{array}$ \\
\hline Age (weeks) & 0.093 & 0.131 \\
\hline Birth Weight (range) & 0.336 & 0.343 \\
\hline $\begin{array}{l}\text { pH Prior to Hypothermia } \\
\text { (range) }\end{array}$ & 0.756 & 0.784 \\
\hline Base Excess (range) & 0.852 & 0.879 \\
\hline $\begin{array}{l}\text { Seizures Prior to Hypothermia } \\
\text { (Yes/No) }\end{array}$ & 0.858 & 0.879 \\
\hline Haematocrit (numeric) & 0.828 & 0.832 \\
\hline Hemoglobin (numeric) & 0.687 & 0.693 \\
\hline Platelet count (numeric) & 0.652 & 0.738 \\
\hline $\begin{array}{l}\text { Period Between Birth And } \\
\text { Starting Hypothermia (hours) }\end{array}$ & 0.612 & 0.648 \\
\hline Hypoglycaemia (Yes/No) & 0.189 & 0.284 \\
\hline C-reactive protein (CRP) & 0.316 & 0.410 \\
\hline Sepsis (Yes/No) & 0.171 & 0.376 \\
\hline $\begin{array}{l}\text { Seizures During Hypothermia } \\
\text { (Yes/No) }\end{array}$ & 0.519 & 0.605 \\
\hline $\begin{array}{l}\text { Initial Brain Ultrasound } \\
\text { (Normal/Abnormal) }\end{array}$ & 0.192 & 0.343 \\
\hline
\end{tabular}

neurodevelopmental examinations performed by child neurologists and psychologists. The simplicity of the questionnaire makes it very affordable for less developed child health care systems, but the results are probably not as well defined as with more sophisticated tools, such as Bayley Scale of Infant Development.

Duration of follow up was one of the issues of this study because all our patients were not followed up for the same time. There are no studies showing how long follow up period is needed for more accurate prediction of neurodevelopmental follow up in these children, and common sense would be that it should be as long as possible, but Azzopardi et al. (2012) found in their study that there were no significant differences in clinical characteristics, aEEG prior to cooling, and age in hours after birth when cooling was started between the infants with and without 2-year outcome data available (20).

On the part of gross and fine motor development we had little less good results. About 31\% of children were having clearly abnormal gross motor development (half of them with hemiparesis) and further $10 \%$ were in retesting zone. Some $26 \%$ of our group had abnormal fine motor develop-

TABLE 5. Statistical significance of correlation between neurodevelopmental outcome and some neurological findings at discharge from the hospital

\begin{tabular}{llllll}
\hline At discharge & $\begin{array}{l}\text { Plantar grasp } \\
\text { reflex }\end{array}$ & $\begin{array}{l}\text { Palmar grasp } \\
\text { reflex }\end{array}$ & Muscle tone & Moro reflex & Overall score \\
Asymp. sig. (2-tailed) & 0.392 & 0.360 & 0.316 & 0.204 & 0.207 \\
$\begin{array}{l}\text { Exact sig. (1-tailed sig.) } \\
\text { Not corrected for ties }\end{array}$ & 0.522 & 0.446 & 0.410 & 0.292 & 0.235
\end{tabular}

Developmental outcome was also similar, with good results on regular neurodevelopmental follow up examinations. That was confirmed by the results obtained through ASQ-3. The results were really encouraging in the domains of communication, problem solving and personal-social performances, with normal behavior in about $70 \%$ of patients. Testing the reliability of ASQ-3 in these conditions, regarding the issues of sensitivity, specificity, positive predictive value, negative predictive value, interobserver reliability remains uncertain (17), but we had good correlation with structured ment, but with further $37 \%$ of children in retesting zone. All these results are quite comparable to the studies mentioned above.

TOBY report (11) finds $27 \%$ of patients with severe neurodevelopmental disability in cooled group, and survival without neurologic abnormality in 44\%. They also find a normal GMFCS score in $71 \%$, which is somehow higher than our results. All those follow ups were quite short and we need longer periods, as a meta-analysis from 2010 states: "Continued follow up of the children enrolled in the studies included in our 
meta-analysis is essential to determine whether these benefits are maintained in later childhood" (18).

Prior to starting cooling, during cooling and after it we recorded numerous parameters. We tried to see if some of them had any kind of correlation with neurodevelopmental outcome, but statistical methods used were restricted by a small number of patients in our group. We were not able to show that any of the studied parameters had statistically significant influence on neurodevelopmental outcome, even the neurological examination at discharge from the hospital. We think that for such studies, much larger groups of patients are needed, and we need to have more multicenter studies dealing with this matter. Not too many studies have addressed this problem until now. Wyatt et al. (21) on a much larger sample of 218 children found a correlation of developmental outcome with treatment, lower encephalopathy grade, lower birth weight, greater aEEG amplitude, absence of seizures, and higher Apgar score, with better outcomes for children with these parameters. Bennet et al. (22) make a good point in emphasizing the need for better understanding of the potential role of biomarkers for HIE.

The need to perform aEEG before starting cooling, in the process of recruitment of candidates for therapeutic hypothermia for perinatal asphyxia remains one of greater controversies in this method. At the beginning of follow up period, our hospital did not have aEEG equipment, and we only had it for the last year of our work. In a recent prospective study (23), the authors found that the aEEG background pattern at $<9$ hours did not significantly enhance the predictive value of HIE stage at $<6$ hours in predicting death and disability at 18 months. Other researchers investigated the abilities of aEEG recordings during cooling and found that the recovery of the background pattern within 24 hours was associated with a lower rate of disability (defined as death, cerebral palsy, or developmental quotient <85) at 2 years (24), and that the time to normalize aEEG was a better predictor than the time to establish normal sleep-wake cycling (25). On the other hand, some large randomized trials included aEEG recordings in the recruitment process for therapeutic hypothermia to prevent $\operatorname{HIE}(11,15,16)$.

From the perspective of our limited experience and first steps in applying therapeutic hypothermia for perinatal asphyxia, we think that the results we are getting are highly promising. Our relatively small number of patients and limitations of study design (not a randomized, controlled study) make our conclusions less reliable, but we think that this can be a solid base for starting assessing the effects of therapeutic hypothermia in countries with limited health care resources. This study shows that improved managing of patients at risk of severe HIE can affect morbidity and mortality rates in less developed countries where this problem is much more present.

\section{Abbreviations:}

HIE - hypoxic-ischemic encephalopathy aEEG - Amplitude Integrated Electroencephalography ASQ-3 - Ages and Stages Questionnaire, $3^{\text {rd }}$ edition

\section{NOVČANA POTPORA/FUNDING}

Nema/None

\section{ETIČKO ODOBRENJE/ETHICAL APPROVAL}

Nije potrebno/None

\section{DOPRINOSI AUTORA/DECLARATION OF AUTHORSHIP}

Svi autori jednako su doprinijeli izradi rada/All authors have equally contributed to a manuscript writing

\section{SUKOB INTERESA/CONFLICT OF INTEREST}

Autori su popunili the Unified Competing Interest form na www.icmje.org/ coi_disclosure.pdf (dostupno na zahtjev) obrazac i izjavljuju: nemaju potporu niti jedne organizacije za objavljeni rad; nemaju financijsku potporu niti jedne organizacije koja bi mogla imati interes za objavu ovog rada u posljednje 3 godine; nemaju drugih veza ili aktivnosti koje bi mogle utjecati na objavljeni rad./All authors have completed the Unified Competing Interest form at www.icmje.org/coi_disclosure.pdf (available on request from the corresponding author) and declare: no support from any organization for the submitted work; no financial relationships with any organizations that might have an interest in the submitted work in the previous 3 years; no other relationships or activities that could appear to have influenced the submitted work.

\section{REFERENCES}

1. Lawn JE, Kerber K, Enweronu-Laryea C, Cousens S. 3.6 million neonatal deaths - what is progressing and what is not? Semin Perinatol. 2010;34:371-86. http://dx.doi.org/10.1053/j.semperi.2010.09.011

2. Levene MI, Sands C, Grindulis H, Moore JR. Comparison of two methods of predicting outcome in perinatal asphyxia. Lancet. 1986;8472:67-9. http://dx.doi.org/10.1016/S0140-6736(86)90718-X

3. Kurinczuk JJ, White-Koning M, Badawi N. Epidemiology of neonatal encephalopathy and hypoxic-ischaemic encephalopathy. Early Hum Dev. 2010;86:329-38. http://dx.doi.org/10.1016/j.earlhumdev.2010.05.010

4. Vannucci RC. Current and potentially new management strategies for perinatal hypoxic-ischemic encephalopathy. Pediatrics. 1990;85:961-8.

5. Gunn AJ, Bennet L. Fetal hypoxia and patterns of brain injury: insights from animal models. Clin Perinatol. 2009;36:579-93. http://dx.doi.org/10.1016/j.clp.2009.06.007

6. Higgins RD, Raju T, Edwards AD, et al. Hypothermia and other treatment options for neonatal encephalopathy: An executive summary of the Eunice Kennedy Shriver National Institute of Child Health and Human Development Workshop. J Pediatr. 2011;159:851-8. http://dx.doi.org/10.1016/j.jpeds.2011.08.004

7. Towfighi J, Housman C, Heitjan DF, et al. The effect of focal cerebral cooling on perinatal hypoxic-ischemic brain damage. Acta Neuropathol. 1994;87:598-604. http://dx.doi.org/10.1007/BF00293321

8. Marion DW, Penrod LE, Kelsey SF, et al. Treatment of traumatic brain injury with moderate hypothermia. N Engl J Med. 1997;336:540-6. http://dx.doi.org/10.1056/NEJM199702203360803

9. Wyatt JS, Gluckman PD, Liu PY, et al. Determinants of outcomes after head cooling for neonatal encephalopathy. Pediatrics. 2007;119:912-21. http://dx.doi.org/10.1542/peds.2006-2839

10. Shankaran S, Laptook AR, Ehrenkranz RA, et al. Whole-body hypothermia for neonates with hypoxic-ischemic encephalopathy. N Engl J Med. 2005;353:1574-84. http://dx.doi.org/10.1056/NEJMcps050929

11. Azzopardi DV, Strohm B, Edwards AD, et al. Moderate hypothermia to treat perinatal asphyxial encephalopathy. N Engl J Med. 2009;361:1349-58. http://dx.doi.org/10.1056/NEJMoa0900854 
12. Jacobs S, Morley CJ, Inder TE, ICE Collaboration. Whole-body hypothermia for term and near-term newborns with hypoxic-ischemic encephalopathy: a randomized controlled trial. Arch Pediatr Adolesc Med.

2011;165:692-700. http://dx.doi.org/10.1001/archpediatrics.2011.43

13. Ikeda K, Ikeda T, Taniuchi H, Suda S. Comparison of whole-body cooling and selective head cooling on changes in urinary 8-hydroxy-2-deoxyguanosine levels in patients with global brain ischemia undergoing mild hypothermia therapy. Med Sci Monit. 2012;18:CR409-14. http://dx.doi.org/10.12659/MSM.883208

14. Hoehn T, Hansmann G, Bührer C, et al. Therapeutic hypothermia in neonates. Review of current clinical data, ILCOR recommendations and suggestions for implementation in neonatal intensive care units. Resuscitation. 2008;78: 7-12.

http://dx.doi.org/10.1016/j.resuscitation.2008.04.027

15. Azzopardi D, Strohm B, Edwards AD, et al. Treatment of asphyxiated newborns with moderate hypothermia in routine clinical practice: how cooling is managed in the UK outside a clinical trial. Arch Dis Child Fetal Neonatal Ed. 2009;94: F260-4. http://dx.doi.org/10.1136/adc.2008.146977

16. Thoresen M. Hypothermia after perinatal asphyxia: Selection for treatment and cooling protocol. J Pediatr. 2011;158 (Suppl 2):e45-9. http://dx.doi.org/10.1016/j.jpeds.2010.11.013

17. Gul Kapci E, Kucuker S, Uslu RI. How applicable are ages and stages questionnaires for use with Turkish children? Topics in Early Childhood Special Education 2010;30:176-88. http://dx.doi.org/10.1177/0271121410373149

18. Lindsay NM, Healy GN, Colditz PB, Lingwood BE. Use of the ages and stages questionnaire to predict outcome after hypoxic-ischaemic encephalopathy in the neonate. J Paediatr Child Health. 2008;44:590-5. http://dx.doi.org/10.1111/j.1440-1754.2008.01388.x

19. Schonhaut L, Armijo I, Schönstedt M, Alvarez J, Cordero M. Validity of the ages and stages questionnaires in term and preterm infants. Pediatrics. 2013;131:e1468-74. http://dx.doi.org/10.1542/peds.2012-3313
20. Edwards AD, Brocklehurst $\mathrm{P}$, Gunn AJ, et al. Neurological outcomes at 18 months of age after moderate hypothermia for perinatal hypoxic ischaemic encephalopathy: synthesis and meta-analysis of trial data. BMJ. 2010;340:363. http://dx.doi.org/10.1136/bmj.c363

21. Wintermark P, Hansen A, Gregas MC, Soul J, Labrecque M, Robertson RL, Warfield SK. Brain perfusion in asphyxiated newborns treated with therapeutic hypothermia. AJNR. 2011;32:2023-9. http://dx.doi.org/10.3174/ajnr.A2708

22. Azzopardi D, Strohm B, Linsell L, et al. Implementation and conduct of therapeutic hypothermia for perinatal asphyxial encephalopathy in the UK - Analysis of National Data. PLoS ONE. 2012;7:e38504. http://dx.doi.org/10.1371/journal.pone.0038504

23. Wyatt JS, Gluckman PD, Liu PY, et al. Determinants of outcomes after head cooling for neonatal encephalopathy. Pediatrics. 2007;119:912-21. http://dx.doi.org/10.1542/peds.2006-2839

24. Bennet L, Booth L, Gunn AJ. Potential biomarkers for hypoxic-ischemic encephalopathy. Semin Fetal Neonatal Med. 2010;15:253-60. http://dx.doi.org/10.1016/j.siny.2010.05.007

25. Shankaran S, Pappas A, McDonald SA, et al. Predictive value of an early amplitude integrated electroencephalogram and neurologic examination. Pediatrics. 2011;128:e112-20. http://dx.doi.org/10.1542/peds.2010-2036

26. van Rooij LGM, Toet MC, Osredkar D, van Huffelen AC, Groenendaal F, de Vries LS. Recovery of amplitude integrated electroencephalographic background patterns within 24 hours of perinatal asphyxia. Arch Dis Child Fetal Neonatal Ed. 2005;90:F245-F51. http://dx.doi.org/10.1136/adc.2004.064964

27. Thoresen M, Hellström-Westas L, Liu X, de Vries LS. Effect of hypothermia on amplitude-integrated electroencephalogram in infants with asphyxia. Pediatrics. 2010;126:e131-9. http://dx.doi.org/10.1542/peds.2009-2938 


\title{
SAŽETAK
}

\section{Neurorazvojni ishod nakon terapijske hipotermije zbog perinatalne asfiksije}

\author{
S. Zubčević, S. Heljić, R. Spahović, I. Kalkan, S. Terzić, M. Sadiković
}

Rezultati raznih ispitivanja govore u prilog neuroprotektivnom učinku terapijske hipotermije u terminske novorođenčadi s hipoksično-ishemijskom encefalopatijom. Mi smo procjenjivali preživljenje i neurorazvojni ishod novorođenčadi podvrgnute ovom postupku te čimbenike koji bi mogli imati utjecaja na taj ishod. Postupak pothlađivanja na temperaturi od 33,5 ㄷ kroz 72 sata te 6-satno razdoblje utopljavanja primijenjen je kod novorođenčadi gestacijske dobi više od 36 tjedana i manje od 6 sati života s umjerenom do teškom asfiksijskom encefalopatijom. Ispitivane mjere ishoda bile su smrt i neurorazvojne značajke. Od listopada 2010. do listopada 2013. godine procijenjeno je 25 djece, medijan gestacijske dobi 40 tjedana, porođajna masa 3470 g, APGAR 2/4 i pH kod prijma u bolnicu 7,02. Četvero (16\%) djece je umrlo, a dvojeje izgubljeno tijekom razdoblja praćenja. U dobi konačne procjene razvojne kategorije komunikacije bile su normalne u 68,4\%, rješavanja problema u 73,7\%, osobne-socijalne u 68,4\%, grube motorike u 57,9\% i fine motorike u 36,8\% djece, ali uz izraženu potrebu ponovnog testiranja u ovom području. Sedmero od 19 (36,8\%) bolesnika imalo je potpuno normalne razultate u svih pet kategorija, dok su nenormalni razultati u svih pet kategorija zabilježeni u troje (15,8\%) bolesnika. Nijedan od 18 parametara koji su korelirani s neurorazvojnim ishodom nije se pokazao statistički značjanim. Elektroencefalografija integrirane amplitude provedena je u desetoro bolesnika, a najizraženiji nalaz bila je isprekidana aktivnost u osmero bolesnika. Zaključno, relativno mali broj bolesnika i ograničenja ove studije ne dopuštaju nikakve dalekosežnije zaključke, ali smatramo da ova metoda može osigurati bolje preživljenje i manje neuroloških posljedica kod bolesnika s hipoksično-ishemijskom encefalopatijom.

Ključne riječi: perinatalna asfiksija hipotermija; novorođenče 